УДК 687:7.012 7.013«1950-2010»

DOI https://doi.org/10.24919/2308-4863.1/30.212197

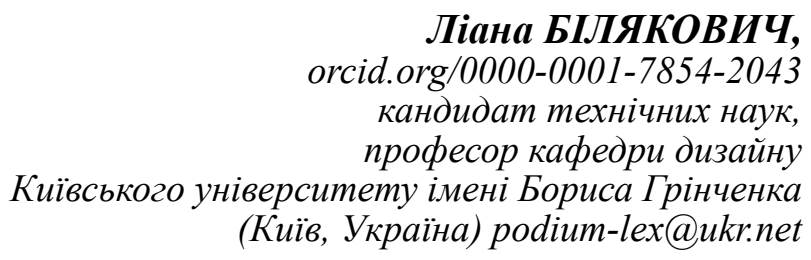

Олександра ПЕНЧУК,

orcid.org/0000-0002-3092-9780

кандидат технічних наук,

доиент кафедри дизайну і технологій

Київського національного університету культури і мистеитв

(Київ, Україна) stolorz17@ukr.net

\title{
ІНТЕРПРЕТАЦІЯ КОСТЮМА ДРУГОЇ ПОЛОВИНИ ХІХ СТ. В ДИЗАЙНІ ЖІНОЧОГО ОДЯГУ 1950-2010-Х РР.: ОБРАЗНІ ТА ФОРМАЛЬНО-КОНСТРУКТИВНІ ОСОБЛИВОСТІ
}

\begin{abstract}
Охарактеризовано образні та формально-конструктивні особливості інтерпретаиії костюма другої половини XIX ст. в дизайні жіночого одягу 1950-2010-х рр. Доведено, щуо соиіопсихологічною передумовою інтересу до неорокайльного вбрання у повоєнні десятиліття слугувала його пластична виразність і втілення ідеалів жіночності, вишуканості, розкоші. Проаналізовано інтерпретації костюма другої половини ХІХ ст. у колекціях стилю «Nеw Look», моделяx Christian Dior, Jacques Fath, Elsa Schiaparelli, Cristobal Balenciaga. Встановлено, цио ї̈ особливостями стали асочіативне відсилання до семантосфери історичних джерел, адаптивне застосування ретроспективних форм у їх підпорядкуванні стилістиці «New Look», поєднання в одній моделі елементів костюмів рококо і різних десятиліть ХІХ ст., світського і традииійного народного вбрання.

Охарактеризовано передумови, образні та формально-конструктивні особливості звернення до костюма другої половини XIX cm. на трунті постмодерністського еклектичного історизму 1980-2010-х рр. у колекціях Yves Saint-Laurent, Christian Lacroix, Gianfranco Ferre, Vivienne Westwood, John Galliano, John Galliano, Alexander McQueen, Rei Kawakubo, Valentino, Chanel. Bстановлено, що основними напрямами творчого осмислення костюма другої половини ХІХ ст. у дизайні жіночого одягу 1980-2010-х рр. стали: створення ємного лірико-поетичного образу на основі «иілісного тексту» історичного вбрання иляхом стилізаџіï, інтерпретації, асоціації; поєднання історичних елементів з елементами костюмів інших епох, класикою, актуальними одяговими формами; інтеграція у жіночий одяг елементів чоловічого костюма другої половини ХІХ сm. Доведено, щзо основними історичними джерелами дизайнерських інтерпретацій слугували силуети суконь другої половини ХІХ ст., їх форми $і$ конструкuіiі, ліфр-«кіраса», турнюр, трен, рукав-gigot, сюртук, жилет, ичиліндр, капелюх-казанок.
\end{abstract}

Ключові слова: неорококо, стиль «New Look», постмодерністський еклектичний історизм.

Liana BILYAKOVYCH, orcid.org/0000-0001-7854-2043 Candidate of Technical Sciences, Professor at the Design Department Borys Hrinchenko University of Kyiv (Kyiv,Ukraine) podium-lex@ukr.net

Aleksandra PENCHUK, orcid.org/0000-0002-3092-9780 Candidate of Technical Sciences, Associate Professor at the Department of Design and Technology Kyiv National University of Culture and Arts (Kyiv,Ukraine)stolorz17@ukr.net

\section{THE INTERPRETATION OF THE COSTUME OF THE SECOND HALF OF XIX CENTURY IN WOMEN'S CLOTHING DESIGN OF 1950S - 2010S: IMAGES AND FORMAL CONSTRUCTIVE FEATURES}

The imaginative and formal-structural features of interpretation of the costume of the second half of the $19^{\text {th }}$ century in the design of the women's clothes in the 1950s - 2010s have been characterized. It has been proven that 
the sociopsychological prerequisites for the interest in neo-rocaille costume in the postwar decade were its plastic expressiveness and embodiment of the ideals of femininity, elegance, and luxury. The interpretations of the costume of the second half of the $19^{\text {th }}$ century have been analyzed in New Look style collections and in the works of Christian Dior, Jacques Fath, Elsa Schiaparelli, Cristobal Balenciaga. It has been noted that its features were the associative reference to the semantosphere of historical sources, adaptive use of retrospective forms in their subordination to the New Look style, combination of the elements of Rococo costumes and costumes of different decades of the $19^{\text {th }}$ century in one design, as well as fashionable and traditional folk clothes.

The prerequisites, and the imaginative and formal-structural features of the appeal to the costume of the second half of the $19^{\text {th }}$ century within the postmodern eclectic historicism of the 1980s - 2010s in the collections of Yves SaintLaurent, Christian Lacroix, Gianfranco Ferre, Vivienne Westwood, John Galliano, John Galliano, Alexander McQueen, Rei Kawakubo, Valentino, Chanel have been characterized. It has been determined that the main directions of creative interpretation of the costume of the second half of the $19^{\text {th }}$ century in the design of the women 's clothes in the 1980s 2010s were: creation of capacious lyric-poetic image based on the "integral text" of the historical clothes by the way of stylization, interpretation and association; combination of historical elements with the elements of the costumes of other epochs, classic, modern outfit; integration of the elements of men's costume of the second half of the $19^{\text {th }}$ century into the women 's clothes. It has been proven that the main historical sources of design interpretations were the silhouettes of dresses of the second half of the $19^{\text {th }}$ century, their shapes and designs, the cuirass-bodice, the tournure, the sacque, the gigot sleeve, the frockcoat, the waistcoat, the cylinder, and the bowler.

Key words: neo-Rococo, New Look style, postmodern eclectic historicism.

Постановка проблеми. Звернення до художніх стилів і костюмів минулих епох $\epsilon$ наскрізною тенденцією моди і дизайну одягу XIX - початку XXI ст. $\mathrm{У}$ різні періоди предметом зацікавлень дизайнерів поставали певні історичні костюми чи сукупність стильових форм, інтерпретація яких одержала визначення «дизайн-історизм» (Ванькович, 2018: 25; Ванькович, 2004: 113; Галудзіна-Горобець, 2019: 5). Першим його проявом стали ретроспекції XIX ст., пов'язані з «відкриттям» Стародавнього Сходу, античності, готики, Ренесансу, бароко, рококо. Найбільш яскравим виразом тенденції є історизм 1980-2010-х рр., заснований на постмодерністському еклектичному поєднанні й іронічній, пародійній, ігровій інтерпретації стильових форм.

Чільне місце в дизайнерських ретроспекціях 1950-2010-х рр. посіли інтерпретації костюма другої половини XIX ст. - його окремих елементів, силуету, декору, форм.

Аналіз досліджень. Незважаючи на частотність творчого переосмислення елементів європейського костюма другої половини XIX ст. у колекціях провідних світових дизайнерів 1950-2010-х рр., комплексне, послідовне дослідження питання сьогодні відсутнє, а його окремі аспекти висвітлено у контексті ширших проблем.

Так, у річищі історії моди, творчості дизайнерів та еволюції пошукових стратегій Будинків Мод звернення до костюма другої половини XIX ст. розглянуто Д. Єрмиловою (Ермилова, 2004), Ш. Зеллінг (Зеллинг, 1999), О. Шевнюк (Шевнюк, 2008). Оглядово прообрази сучасної моди в загальнохудожніх тенденціях минулих епох охарактеризовано С. Ванькович (Ванькович, 2004).

У дисертації М. Кир'янова відзначено іронічність, пародійність, цитатність комбінування елементів історичних костюмів різних періодів, зокрема й другої половини XIX ст., у творчості провідних дизайнерів 1980-2010-х рр. (Кирьянов, 2011: 50, 52, 89, 102-103, 105, 109-110, 118-120, 122-124, 154-155).

Е публікації О. Москвина (2014) здійснено ретроспективний аналіз проявів історичних мотивів у модній формі костюма і вказано на зростання ïх значення в дизайні одягу 1980-х - 2010-х pp. (Москвин, 2014: 272-273). Відзначено дискретність дизайнерських ретроспекцій, запозичення форм, силуетів, деталей різночасових костюмів «в межах моделей однієї колекції» (Москвин, 2014: 273). Підкреслено «адаптивне застосування» історичних елементів згідно із сучасними естетичними пріоритетами, тенденціями моди, установками сприйняття (Москвин, 2014: 271-273). У дисертації науковця (Москвин, 2015) охарактеризовано асортимент, методи проектування, конструкції чоловічого плечового одягу XIX ст., розроблено базу історичних прототипів та алгоритми розробки креслень для вирішення актуальних художньо-проектних завдань.

У контексті дослідження історизму у дизайні одягу другої половини XX - початку XXI ст. інтерпретації костюма 1850-1890-х рр. проаналізовано у дисертації В. Галудзіної-Горобець (ГалудзінаГоробець, 2019), виконаній під керівництвом проф. Л. Білякович у межах наукових досліджень кафедри дизайну і технологій КНУКіМ.

Теоретико-методологічне підгрунтя публікації утворили праці вітчизняних і зарубіжних науковців, присвячені ретроспективізму в дизайні одягу: Л. Білякович (Білякович, 2018), С. Ванькович (Ванькович, 2004), В. Галудзіної-Горобець (Галудзіна-Горобець, 2018; Галудзіна-Горобець, 2019), 
А. Демшиної (Демшина, 2013), О. Москвина (Москвин, 2012; Москвин, 2013; Москвин, 2014).

Отже, метою статті $\epsilon$ розкриття образних i формально-конструктивних особливостей інтерпретації костюма другої половини XIX ст. в дизайні жіночого одягу 1950-2010-х рр.

Виклад основного матеріалу. Аналіз доробку світових дизайнерів і творчих стратегій Будинків Мод дозволяє стверджувати, що адаптивне застосування силуету, форм, конструкцій, декору костюма другої половини XIX ст. є однією із провідних тенденцій дизайну одягу 1950-2010-х рр. Передумовою дизайнерських зацікавлень слугувала пластична виразність історичного костюма, його суголосність естетичним пріоритетам доби та здатність включення у нові культурні контексти зі збереженням «вихідних семантичних полів».

Відомий під назвою «другого рококо» або «неорококо», стиль костюма 1850-1870-х рр. сформувався у Франції, на грунті жадання буржуазії часів Другої імперії Луї Філіпа (Наполеона III) (1852-1870) уподібнитися аристократії часів сильної монаршої влади, блиску Версалю $\mathrm{i}$ «fêtes galantes». Невипадково основою стилеутворення в жіночому костюмі $1850-1870-\mathrm{x} \mathrm{pр.} \mathrm{стали}$ рокайльні форми, що надавали постаті виразності та витонченості: вузький ліф на корсеті, широка спідниця на жорсткому каркасі, Х-подібний силует. Поширенню нового стилю сприяли смаки імператриці Євгенії, яка обожнювала МаріюАнтуанетту і моду XVIII ст.

У неорокайльному костюмі зберігся корсет, що стягував талію, й широка спідниця на кринолінах, яка у 1860-х рр., завдяки новим легким конструкціям, збільшилася в об'ємі ззаду, стала пласкою спереду й утворила новий, «профільний силует». У 1870-х рр. профіль нового костюма увиразнив турнюр (подушечка, котру підкладали під сукню ззаду), моду на який започаткував перший французький кутюр' $€$, творець стилю неорококо, англієць Чарльз Фредерік Ворт. Іноді турнюр заміняли невеликими підкладками або драпіруваннями тканин, популярність яких тривала до 1890-х рр. Виразності силуету сприяла нова форма подовженого корсету-«кіраси» і задрапірований на турнюрі шлейф - трен. Завдяки Ч. Ф. Ворту з 1889 р. у моду повернулися рукави-gigot, об'ємні вгорі та вузькі біля ліктя. У 1870-х рр. у моду увійшли цільнокроєні сукні «princesse», які підкреслювали природні форми жіночого тіла і створювали виразний гнучкий силует.

Істотний вплив на моду другої половини XIX ст. здійснило формування нового буржуазного ідеалу жінки - доброчинної, вишуканої, свідчення соці- альної успішності чоловіка і заможності сім'ї. Звідси - перевантаженість, пластична надлишковість, строкатість, різнофактурність неорокайльного костюма, втрата властивої аристократичному вбранню XVIII ст. цілісності силуету, декору, форм. У дизайні одягу останніх десятиліть XIX ст. простежуються дві різноспрямовані тенденції: зростання вишуканості, чуттєвості, еротизму й пошук більш функціональних конструкцій вбрання.

Чоловічий костюм 1850-1870-х рр. створював образ ділової, впевненої, респектабельної людини - господаря власного життя. У моду увійшли сюртуки в тон смугастим або клітчастим брюкам і вестон - прототип піджака. Останній разом із жилетом і брюками утворив класичну «тріаду», яку $з$ 1860-х рр. відшивали 3 однорідних тканин. У 1850-х популярності набула візитка, що зберегла крій сюртука, однак мала відкриті груди, лацкан і заокруглені пілки. У наступне десятиліття вона стала обов'язковим складником гардеробу ділової людини і буржуа (Мерцалова, 2001: 330). У місті носили пальто, в мандрівках - однобортний, без рукавів, із пелериною і відкладним коміром «реглан» або «макферлейн» (Мерцалова, 2001: 338). Головним убором слугував циліндр або круглий капелюх із прямими полями.

На початку XX ст. під впливом урбанізації, динамізації життя, зростання суспільної ролі середнього класу й емансипації жінки на зміну вишуканим, гіперболізованим, контрастним формам прийшов прямий, уподібнений до античних хітонів чи східного кімоно вільний простий силует. Нові принципи формотворення зреалізували Mariano Fortuny, Paul Poiret, Madeleine Vionnet, Madame Gres. Після Першої світової війни поширився андрогінний стиль La Garconne, інспірований однойменним романом В. Маргерітта (1922) та ідеалом активної, незалежної жінки. Ритми сучасності відобразили короткі стрижки-клош, вільні сукні із заниженою талією, увиразнені вишивкою, яскравим макіяжем, аксесуарами, пір'яними боа. Нові тенденції втілили прямі кардигани, «брюки для яхти», маленькі чорні сукні Coco Chanel. Після Великої депресії 1929 р. у моду увійшли квадратні плечі та підкреслена лінія талії, однак костюм зберігав стриманість форм.

Нова хвиля інтересу до костюма другої половини XIX ст. припала на повоєнне десятиліття і відобразилася у стилі «New Look»: моделях Christian Dior, Pierre Balmain, Jacques Fath, Elsa Schiaparelli, Cristobal Balenciaga, Pierre Cardin. Соціопсихологічним підгрунтям тенденції слугувало прагнення після лихоліть війни відродити ідеал рафінованої жіночої краси й відчути радість, 
вишуканість, естетичну структурованість життя. В аспекті закономірностей динаміки моди, утвердження «New Look» віддзеркалило зміну геометричної та пластичної тенденцій (Гузявичуте, 1977: 56-60), простих кутастих силуетів - гнучкими лініями, контрастом об'ємів, примхливою пластикою форм.

Особливостями інтерпретації неорокайльного костюма у стилі «New Look» стали використання формотворчого потенціалу турнюра і трена та асоціативне відсилання до семантосфери історичних джерел. Так, моделі Christian Dior вирізняли «триєдність жіночності, розкоші та витонченості» (Москвин, 2014: 273), $\mathrm{X}$-подібний силует, гнучкі лінії, контрасти форм. Образній виразності суконь посприяли урочистість драперій атласу, святковий блиск тафти, невагомість прозорого тюлю.

Зокрема, у біло-сріблястій сукні $з$ колекції осінь/зима 1948 р. дизайнер створив профільну домінанту завдяки драпіруванням, що нагадують трен, і урівноважив їх асиметричними горизонтальними драпіруваннями плечей (рис. 1).

Профільний силует, модельований треном, став відзнакою низки моделей Christian Dior 1950-х pp. Асоціативністю позначено образно-пластичне вирішення сукні «Венера» 3 колекції осінь/зима 1949-1950 pp. із треном із сріблястої органзи, асоційованої з морською піною, із якої народилася богиня (рис. 2).

У моделі Christian Dior 1950-х рр. з Музею Інституту костюма Кіото на історичні інспірації вказує вузька вгорі та розширена донизу спідниця із треном силуету «princesse». Значущим у створенні рафінованого, витонченого образу є матовий блиск атласу та поєднання сіро-рожевих і сріблястих барв.

Ще більш виразно інспірації жіночого костюма останньої третини XIX ст. простежуються у творчості французького дизайнера, конкурента Christian Dior, Jacques Fath. Так, у кремовій атласній сукні, створеній майстром для майбутньої королеви Єлизавети II з нагоди ії візиту у Париж (1948), силует формують вузький закритий ліф, оздоблений золотим шитвом, широка спідниця і турнюр, модельований складками тканин. Поєднання силуету «princesse» початку 1880-х рр., трену і стилізованого турнюрубанта зустрічаємо у вечірній атласній сукні 1948 p.

Гіперболізація, асиметрія, сміливі видозміни форм вирізняють інтерпретації костюма другої половини XIX ст. у доробку Elsa Schiaparelli. Так, у сукні 1953 р. дизайнер створила динамічну композицію, поєднавши однотонні ліф із відкритими плечима та широку спідницю з гіперболізованими смугастими треном і рукавом-gigot (рис. 3).

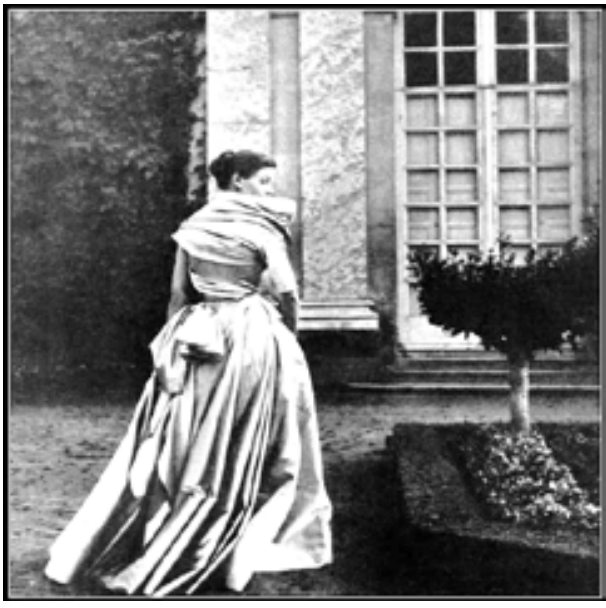

Рис. 1. Christian Dior. Біло-срібляста сукня 3 колекції осінь/зима 1948 р. із профільним силуетом і треном (American Vogue. October. P. 8. Фото Clifford Coffin)

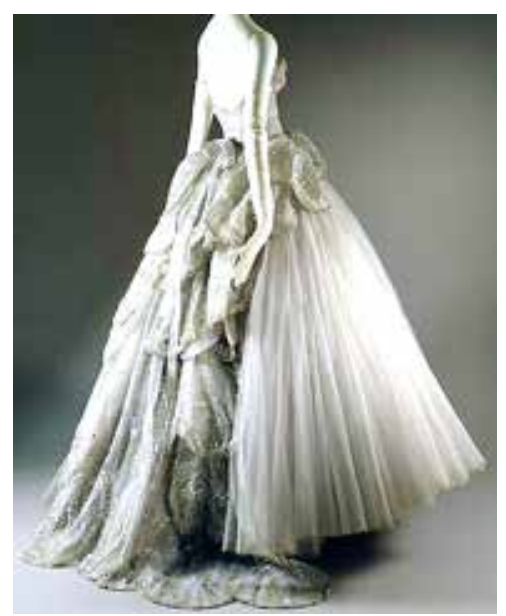

Pис. 2. Christian Dior. Вечірня сукня «Венера». 1950 p. (URL: http://fashmag.ru/christian-dior-1950$\% \mathrm{D} 0 \% \mathrm{~B} 5 / \#$ gallery-6)

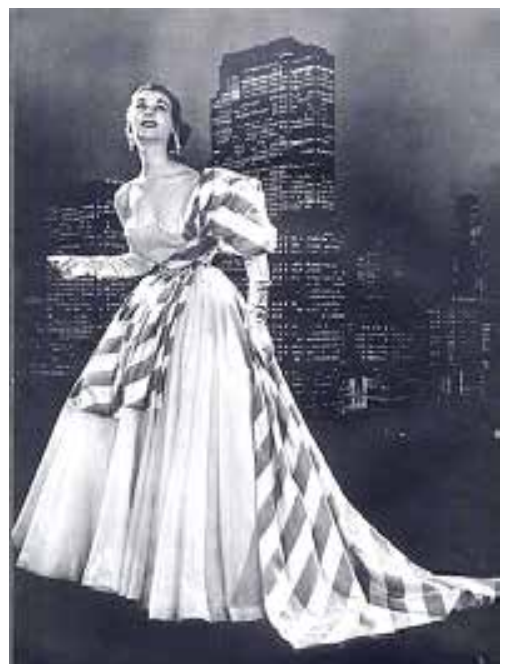

Pис. 3. Elsa Schiaparelli. Сукня 3 асиметричним рукавом-gigot i турнюром. $1953 \mathrm{p}$.

(URL: https://www.pinterest.com/pin/4248865460785725 $92 / ? \mathrm{lp}=$ true) 


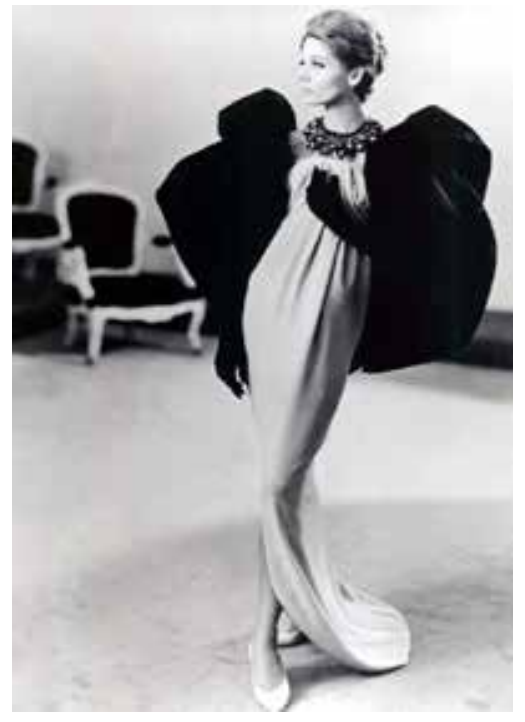

Рис. 4. Cristobal Balenciaga. Сіро-рожева сукня 3 масивною чорною накидкою 3 гіперболізованими рукавами-gigot. Колекція весна/літо 1961 р. Фото

John Rawlings (Ирвин С. Кристобаль Баленсиага. Москва : Слово, 2014. С. 269. (VOGUE. Легенды моды))

Вишуканість, пластична стриманість, використання образоутворюючих можливостей ліній і силуету, бездоганне стилевідчуття, поєднання неорокайльних ремінісценцій зі стилями інших епох і мотивами традиційного іспанського костюма притаманне моделям Cristobal Balenciaga.

Чи ненайбільш цілісне утворчості дизайнера відтворення «тексту» костюма кінця 1860-1870-х рр. шляхом стилізації та адаптивного застосування історичних форм зустрічаємо у рожевій сукні для коктейлю 3 шовкової тафти з вузьким ліфом, відкритими плечима, широкою спідницею, треном і турнюром. Важливого значення у пластиці виробу набуває ритм дрібних горизонтальних драперій спідниці та великих вертикальних турнюра. Особливістю образної концепції моделі $€$ поєднання чуттєвості та ніжності, романтичних «дівочих» нот (колекція весна/літо 1955). Характерне для 1950-х - початку 1960-х рр. поєднання стилізованих елементів жіночого костюма різних десятиліть XIX ст. зустрічаємо у сіро-рожевій сукні, силует якої нагадує «шміз» часів Директорії, а гіперболізовані рукави чорної накидки gigot 1830-х і кінця 1880-х рр. (колекція весна/ літо 1961) (рис. 4).

Історичними асоціаціями позначено білу вечірню сукню $з$ вузьким ліфом, відкритими плечима і розширеним ззаду криноліном, характерним для 1860-х pр. (колекція весна/літо 1953). Перегук із модою XIX ст. засвідчує застосування шовкового фаю - однотонної, щільної, еластичної тканини репсового плетіння з характерною рубчастою фактурою, придатної для м'яких, об'ємних драпірувань. Естетично осмислене зіткнення семантичних культурних полів простежується у доповненні аристократичної, вишуканої сукні жакетом, створеним за мотивами тореадорського chaquetilla. Контрастне поєднання різностильових елементів властиве вечірній сукні 3 чорного шовку силуету «princesse», увиразненій мереживами народного іспанського вбрання (колекція осінь/зима 1961-1962). Семантичною ємністю і «подвійними історичними посиланнями» позначено образне вирішення оксамитової вечірньої сукні з зимової колекції Cristobal Balenciaga 1953 р., $з$ турнюром 3 хвостиками горностаю, асоційованим із королівською мантією XVII-XVIII ст. і жіночим неорокайльним вбранням.

Після мінімалізму 1960-х і «Mix and Maich» 1970-х рр. нова хвиля історичних ретроспекцій, заснованих на постмодерністських грі, іронії, еклектичному, цитатному поєднанні різночасових стильових форм, припала на злам XX-XXI ст. Аналіз колекцій провідних світових дизайнерів засвідчує, що постмодерністська інтерпретація костюма другої половини XIX ст. каталізувалася його внутрішньою естетичною суперечністю: витонченою розкішшю і показним буржуазним шиком, зовнішньою цнотливістю, чуттєвістю, еротизмом.

За образно-формальними ознаками основними напрямами творчого переосмислення костюма другої половини XIX ст. у дизайні жіночого одягу 1980-2010-х рр. стали: 1) створення ємного лірикопоетичного образу на основі «цілісного тексту» історичного вбрання шляхом стилізації, інтерпретації, асоціації (Yves Saint-Laurent, John Galliano, Christian Lacroix, Gianfranco Ferre, Valentino, John Galliano, Alexander McQueen); 2) поєднання історичних елементів 3 елементами костюмів інших епох, класикою, актуальними одяговими формами на засадах пошуку образно-пластичної гармонії або постмодерністського іронічного осмислення (Christian Lacroix, Gianfranco Ferre, John Galliano, Vivienne Westwood, Jean-Paul Gaultier, Valentino, Alexander McQueen, Rei Kawakubo); 3) інтеграція у жіночий одяг елементів чоловічого костюма другої половини XIX ст. (Gianfranco Ferre, Vivienne Westwood, Alexander McQueen та ін.). Основними історичними джерелами дизайнерських інтерпретацій слугували силуети суконь другої половини XIX ст., їх форми і конструкції, ліф-«кіраса», турнюр, трен, рукав-gigot, сюртук, жилет, циліндр, капелюх-казанок.

Прикладом першої групи образно-пластичних рішень $\epsilon$ романтична, вишукана сукня 3 колекції Yves Saint-Laurent haute couture весна/літо 1981 p. 
3 тюлю, кремових мережив, шовку, трикотажу. Історичними «маркерами» моделі стали трен, турнюр, рукав-gigot, популярна у часи Наполеона III парасолька-«омбрель» (Мерцалова, 2001: 347). Особливістю виробу $є$ асоційованість із літературними образами XIX ст., ліричні інтонації, тонка стилізація силуету, форм, декору історичного вбрання.

Асоціації 3 образами класичної літератури XIX ст. - Сонею Мармеладовою зі «Злочину і покарання〉 Ф. Достоєвського, Лізою Калітіною 3 «Дворянського гнізда» I. Тургенєва, Анною Кареніною з однойменного роману Л. Толстого викликають сукні зі стилізованими, гіперболізованими спідницями на кринолінах, турнюрами, тренами, рукавами-gigot (рис. 5) із колекції John Galliano «Втеча юної принцеси Лукреції 3 більшовицької Росії» haute couture осінь/зима 1993-1994 pр. Культурні алюзії увиразнено колористикою, суголосним полотнам К. Сомова поєднанням сутінково-прозорих бузкових, сріблястих, білих, оливкових барв.

Тонка стилізація елементів історичного вбрання простежується у бузковій сукні $з$ турнюром, імітованим драпіруванням тканин, із колекції Christian Lacroix haute couture осінь/ зима 1997-1998 рр. Асоційованість з образом Кармен, дифузія елементів жіночого костюма другої половини XIX ст. та іспанської сукні для фламенко притаманна пристрасно-червоній, із вузьким ліфом, турнюром і треном сукні 3 колекції Christian Lacroix haute couture осінь/ зима 1990-1991 pр. Схоже образне рішення зустрічаємо в червоній сукні з рукавами-gigot, треном, чорним орнаментом, гіперболізованою мантильєю з колекції John Galliano haute couture осінь/зима 2007-2008 pр.

Ліричний, просякнутий музичними інтонаціями образ створено в сукні з колекції Christian Lacroix haute couture осінь/зима 1996-1997 pp.: iз подовженим корсетом-«кірасою», треном, турнюром, рукавами-gigot. Романтичної витонченості моделі надає поєднання пастельних, сіро-рожевих, бузкових, світло-зелених барв. Із сучасними пластичними кодами твір Christian Lacroix поєднує абстрактний головний убір. Пластичну надлишковість і показну розкіш жіночого костюма другого рококо відтворено в сукні Christian Lacroix 3 чорним ліфом, гіперболізованими рукавамиgigot iз пір'їн, чорною мереживною спідницею iз треном і великим рожевим бантом із колекції haute couture осінь/зима 1996-1997 pр. (рис. 6).

$\mathrm{У}$ низці моделей при збереженні цілісності «тексту» історичного костюма та настроєвості

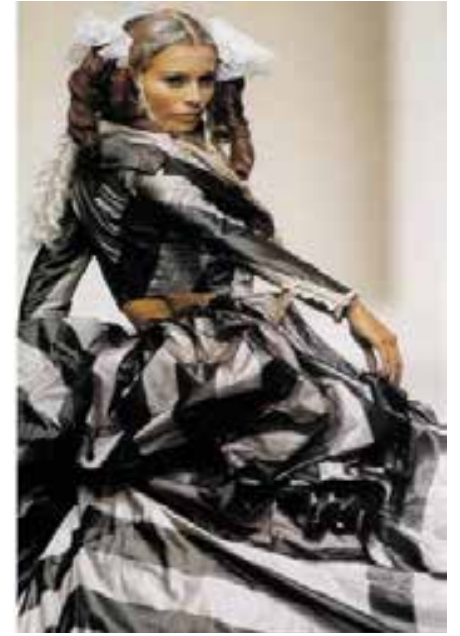

Рис. 5. John Galliano. Колекція «Втеча юної принцеси Лукреції з більшовицької Росії».

Стилізація і гіперболізація форм аристократичного жіночого костюма XIX - початку XX ст.

URL: Princess Lucretia collection 1993 - short interview (URL: https://www.youtube.com/ watch? $\mathrm{v}=\mathrm{miVsEx} 0 \mathrm{eFOE}$ )

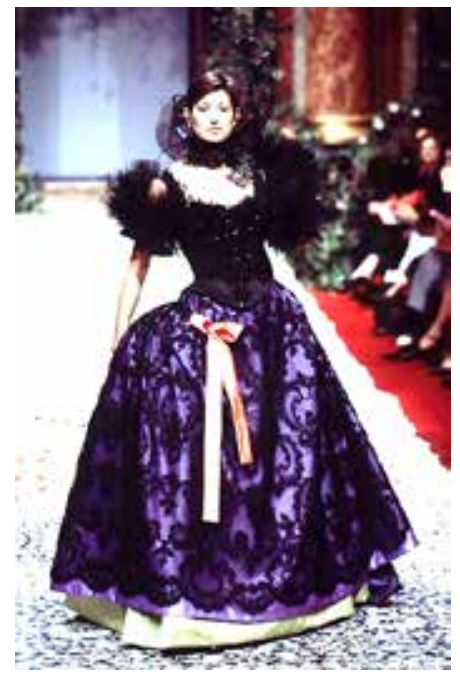

Pис. 6. Christian Lacroix. Сукня з вузьким чорним ліфом, гіперболізованими рукавами-gigot iз пір'їн і чорною мереживною спідницею із треном.

Колекція haute couture осінь/зима 1996-1997 pp.

(URL: https://www.youtube.com/ watch? $=9$ p5pZEMnZ8s)

історичного образу застосовано сучасні методи формотворення, асиметрію i деконструкиію. Так, ігрові постмодерністські ноти у вохристобілу смугасту сукню з вузьким ліфом, спідницею на кринолінах, рукавами-gigot 3 колекції John Galliano haute couture осінь/зима 2007-2008 pp. вносить глибокий бічний розріз. У рожевій сукні тієї ж колекції форми неорокайльного жіночого вбрання модернізовано асиметричними драперіями спідниці. 


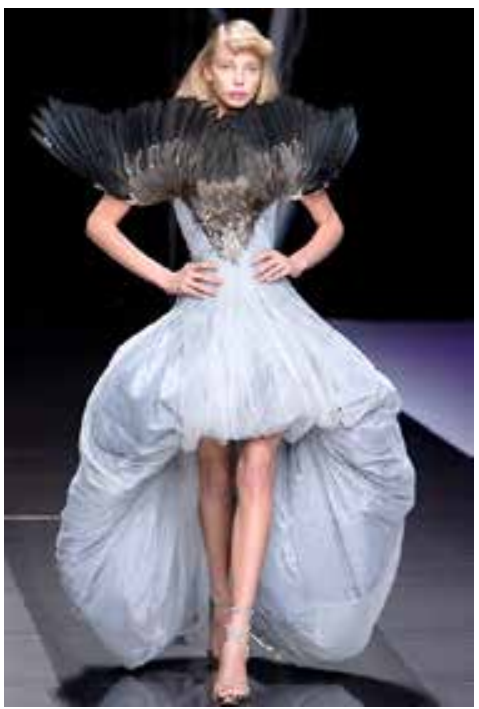

Pис. 7. Alexander McQueen. Доповнення неорокайльних форм орнітологічними мотивами. Колекція prêt-à-porter весна/літо 2008 p. (URL: https://www.pinterest.com/pin/521573200567246101/)

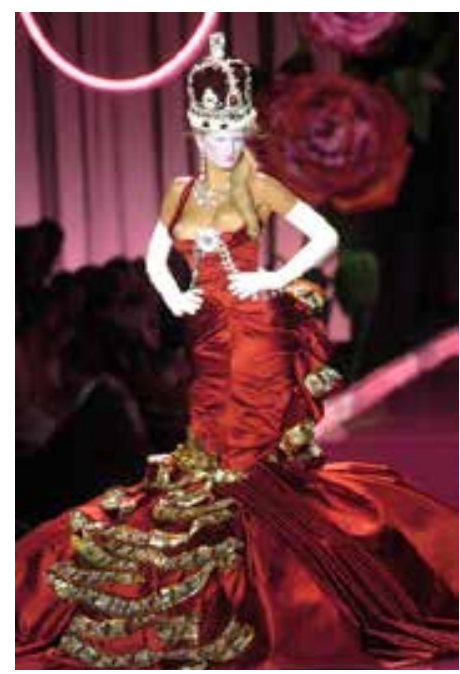

Pис. 8. John Galliano. Створення фантазійного образу імперської величі завдяки гіперболізації тренів, турнюрів, рукавів-gigot. Колекція haute couture осінь/зима 2004-2005 pp.

(URL: https://www.vogue.com/fashion-shows/fall-2004couture/christian-dior)

Прикладом трансформації та нової комбінаторики форм і силуетів неорокайльного вбрання при збереженні ліричних інтонацій та пізнаваності історичних форм є світло-бузкова сукня Alexander McQueen з колекції prêt-à-porter весна/ літо 2008 р., в якій турнюр, вкорочена спереду спідниця на кринолінах і неорокайльний силует поєднано $з$ орнітологічними мотивами, характерними для творчості дизайнера 2000-х рр. (рис. 7).
У низці випадків в інтерпретації історичного костюма задіяно гіперболізацію, переважно тренів і турнюрів, як у колекції Vivienne Westwood весна/ літо 1994 р. та осінь/зима 1994-1995рр. Фантазійний образ імперської величі завдяки необароковій пластичній виразності, гіперболізації тренів, турнюрів, рукавів-gigot, поєднанню пурпурного, блакитного, золотого, білого оксамиту, атласу, шовку, створено в колекції John Galliano haute couture осінь/зима 2004-2005 pp. (Christian Dior, 2004) (рис. 8).

Другу групу образно-пластичних рішень утворюють моделі, в яких елементи історичного костюма другої половини XIX ст. поєднано з класикою або гостро актуальними формами на засадах стильового синтезу, «діалогу», «контрасту-конфлікту».

Одним із найбільш гармонійних образів в аналізованій групі $є$ світло-сірий брючний трикотажний костюм із колекції Christian Lacroix haute couture весна/літо 1988 р., доповнений темно-сірою накидкою зі стилізованими рожевими рукавами-gigot. Схоже образно-пластичне рішення зустрічаємо у бузковій сукні з колекції Christian Lacroix haute couture весна/літо 1991 p. 3 треном і рукавами-gigot, органічно поєднаній із широкими білими брюками.

«Діалог» елементів неорокайльного і сучасного костюмів характерний для вишуканої моделі 3 колекції Alexander McQueen for Givenchy Haute Couture Spring Summer 1999 р. 3 вузьким ліфом, високим комірцем-стійкою, широкою чорнозеленою спідницею, білим мереживним треном, вузькими шкіряними брюками. Відзнакою дизайнерського рішення $є$ інтеграція у жіночу модель нот чоловічого образу завдяки стриманості силуету, колірного рішення, ритму тональних площин (рис. 9). Схожий підхід простежується у сучасній прямій чорній сукні з широкою блакитною стегновою пов'язкою, що імітує турнюр, із колекції Yves Saint-Laurent осінь/зима 1995-1996 pр.

Підпорядкування елементів жіночого костюма другої половини XIX ст. необароковій пластичній виразності притаманне колекціям Christian Lacroix. Так, у сукні з колекції haute couture весна/літо 1988 p. грайливий, романтичний образ створено поєднанням дрібного квіткового принту, міні-кріні, вузького ліфа, гіперболізованого турнюра й асиметричного рукава-gigo. «Діалогічне» зіставлення сучасної сукні, «цитати» турнюра і примхливого головного убору-мушлі зустрічаємо в моделі Christian Lacroix 3 колекції haute couture весна/літо 1988 p.

Іронічний, ігровий постмодерністський образ маленької дівчинки, яка приміряє доросле 
вбрання, формують зіставлення міні-сукні 3 тюлю із треном і турнюром, картонної корони і дитячої сумки в колекції John Galliano fall 2000 ready-towear. Постмодерністську пародійну інтерпретацію костюма другої половини XIX ст. зустрічаємо в сукнях John Galliano з гіперболізованими турнюрами, тренами, рукавами-gigot, написами SPORT або принтами, що імітують шпальти газет (колекція prêt-à-porter осінь/зима 2004-2005) (рис. 10). Поєднання неорокайльних і мілітарних мотивів характерне для вузької оливкової міні-сукні з турнюром із сітчастої тканини, що нагадує давньоримське військове вбрання. Виразності образу додають пояс, браслети, кольє 3 ланцюгів і стилізація лаврового вінця (Chanel haute couture весна/ літо 1994).

Історично інспіровані кемпові еротичні образи створено у колекціях Vivienne Westwood 1990-х pp. Так, у моделях колекції prêt-à-porter осінь/зима 1994-1995 рр. гіперболізований турнюр і трен поєднано $з$ купальниками, надкороткими спідницями, взуттям на високих підборах. Пародійне доповнення класичного смугастого костюма треном, імітованим із білих пір'їн, зустрічаємо в колекції Vivienne Westwood prêt-à-porter весна/літо $1994 \mathrm{p}$.

Естетично осмислений дисонанс тіла і костюма покладено в основу дизайнерського рішення комплекту 3 циліндричним об'ємом, що нагадує турнюр, із колекції Rei Kawakubo осінь/зима 1995 (бренд «Comme des Garçons»). Додаткових відтінків образу надає контраст затишної в'язки, невагомого білого тюлю, романтичного рожевого кольору і постмодерністської деструкції форм.

У межах третьої групи за дизайнерською інтенцією розрізняємо інтеграцію елементів чоловічого костюма XIX ст. у сучасний жіночий на засадах пошуку нової гармонії та еклектичне змішування форм. Прикладом першого типу образно-пластичних рішень $є$ модель Gianfranco Ferre 3 колекції осінь/зима 1983-1984 рр., в якій стилізований темний сюртук поєднано з білим плащем «макферлейн» і циліндром. «Конфліктне» зіставлення плаща-реглану, циліндра i «кітчевого» леопардового малюнку зустрічаємо в моделі Vivienne Westwood 3 колекції prêt-à-porter осінь/ зима 1991 р. Іронічна комбінація фраку, сюртука, капелюха-казанка і стилізованої середньовічної сукні характерна для моделі Alexander McQueen з колекції pre fall 2009 p.

Висновки. Отже, можемо зробити висновок, що творча інтерпретація костюма другої половини XIX ст. $є$ одним із проявів дизайн-історизму й наскрізною тенденцією моди і дизайну

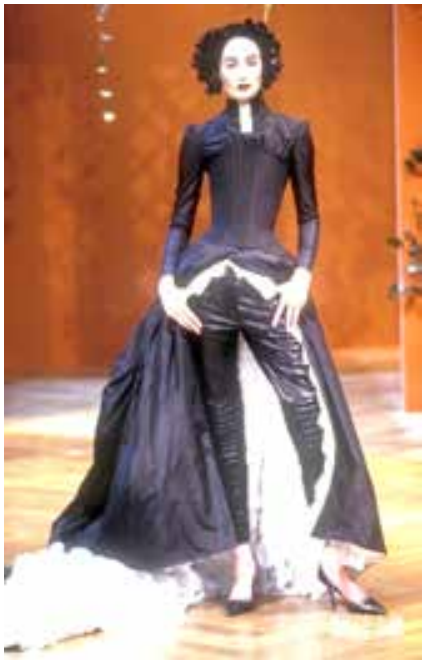

Рис. 9. John Galliano. «Діалогічне» посднання неорокайльних елементів і сучасних шкіряних брюк. Колекція haute couture весна/літо 1999 р. (URL: https://www.pinterest.co.kr/ $\operatorname{pin} / 670684569490528959 /)$

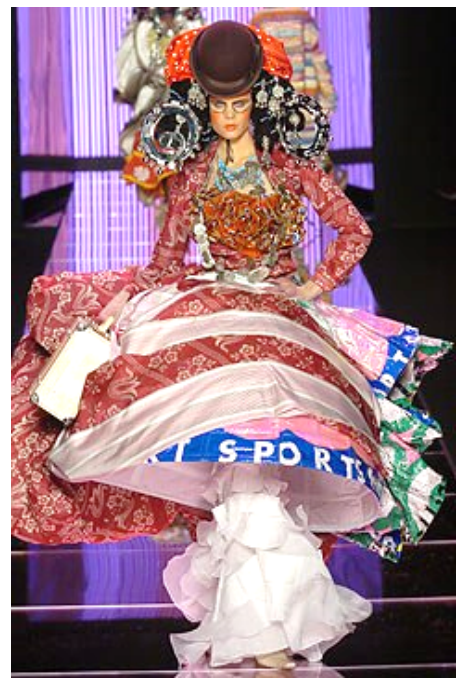

Puc. 10. John Galliano.

Приклад постмодерністського еклектизму.

Спідниця і турнюр із написом «Sport». Колекція prêt-à-porter осінь/3има 2004-2005 pp.

(URL: https://www.youtube.com/watch?v=HtS73O9-fTY)

1950-2010-х рр. Особливо яскраво дизайнерські історичні зацікавлення виявилися в жіночому костюмі, де предметом творчого осмислення постали $\mathrm{X}$-подібний силует із вузьким ліфом і спідницею на кринолінах, профільний силует, силует «princesse», рукави-gigot, трен, турнюр.

Актуалізація форм неорокайльного костюма у 1950-х - на початку 1960-х рр. відбувалася у межах стилю «New Look» і підживлювалася бажанням після лихоліть війни відродити ідеал жінки як утілення елегантності, витонченості, 
краси, повернутися до комфортного, естетично структурованого життя. 3 погляду закономірностей динаміки моди звернення до неорокайльного жіночого вбрання відобразило чергування геометричної та пластичної тенденцій, циклічну зміну кутастих силуетів вишуканою пластикою форм

Особливістю інтерпретації історичного костюма у 1950 - на початку 1960-х рр. стали асоціативне відсилання до семантосфери історичних джерел, триєдність жіночності, розкоші та витонченості, адаптивне застосування ретроспективних форм у їх підпорядкуванні стилістиці «New Look», використання методів стилізації, гіперболізації, асоціації, образоутворюючих можливостей силуету, ритму драперій, асиметричних контрастних форм; поєднання в одній моделі елементів костюмів рококо і різних десятиліть ХІХ ст., світського i традиційного народного вбрання. Перегуком зі стилістикою жіночого вбрання другої половини XIX ст. стало використання мережив, шовкової тафти, шовкового атласу, шовку, шовкового фаю.

Яскравими зразками ретроспекцій одягових форм другої половини XIX ст., насамперед турнюру, трену, рукава-gigot, Х-подібного силуету, профільного силуету, силуету «princesse», стали моделі Christian Dior, Pierre Balmain, Jacques Fath, Elsa Schiaparelli, Cristobal Balenciaga, Pierre Cardin.

Стадіально специфічні інтерпретації костюма другої половини XIX ст. пов’язані 3 «постмодерністським еклектичним дизайн-історизмом» 1980-2010-х pp. та властивими йому іронічним, ігровим осмисленням різночасових стильових форм.
За образно-формальними ознаками основними напрямами творчого переосмислення костюма другої половини XIX ст. в дизайні жіночого одягу 1980-2010-х pp. стали: 1) створення ємного лірико-поетичного образу на основі «цілісного тексту» історичного вбрання шляхом стилізації, інтерпретації, асоціації (Yves Saint-Laurent, John Galliano, Christian Lacroix, Gianfranco Ferre, Valentino, John Galliano, Alexander McQueen); 2) поєднання історичних елементів 3 елементами костюмів інших епох, класикою, актуальними одяговими формами на засадах пошуку образно-пластичної гармонії або постмодерністського іронічного осмислення (Christian Lacroix, Gianfranco Ferre, John Galliano, Vivienne Westwood, Jean-Paul Gaultier, Valentino, Alexander McQueen, Rei Kawakubo); 3) інтеграція у жіночий одяг елементів чоловічого костюма другої половини XIX ст. (Gianfranco Ferre, Vivienne Westwood, Alexander McQueen та ін.). Основними історичними джерелами дизайнерських інтерпретацій слугували силуети суконь другої половини XIX ст., їхні форми та конструкціï, ліф-«кіраса», турнюр, трен, рукав-gigot, сюртук, жилет, циліндр, капелюх-казанок.

Перспективи подальших досліджень полягають у поглибленому комплексному вивченні звернень до історичних художніх стилів і сучасного їм костюма у світовому і вітчизняному дизайні одягу XX - початку XXI ст., аналізі їх циклічності та прогнозуванні актуалізацій історичних одягових форм.

\section{СПИСОК ВИКОРИСТАНИХ ДЖЕРЕЛ}

1. Білякович Л. Темпоральність у структурі модних трендів: сутність, динаміка, прогнозування. Вісник Львівської національної академії мистеитв. 2018. Вип. 36. С. 207-222.

2. Ванькович С. М. Костюм периода историзма (проблема восприятия стилевых прототипов) : дисс. ... канд. искусствоведения : 17.00.04 / Российская Академия Художеств ; Институт живописи, скульптуры и архитектуры им. И. Е. Репина. Санкт-Петербург, 2001. 187 с.

3. Ванькович С. М. Прообразы современной моды в аспекте общехудожественных тенденций прошлых епох. Мода и дизайн: исторический опыт новые технологии. Спец. вып. Вестника СПГУТД. 2004. С. $12-123$.

4. Галудзіна-Горобець В. І. Історизм у дизайні одягу другої половини XX - початку XXI ст. : генеза, динаміка, стильові особливості : дис. ... канд. мистецтвознавства. 17.00.07. Київ : Київський національний університет культури і мистецтв, 2019. 242 с.

5. Гузявичуте Р. А. Исследование стабильных признаков в проектировании одежды XX века : дисс. ... канд. техн. наук : 07.00.06. Москва, 1977. 183 с.

6. Демшина А. Ю. Ретроспективизм в современной моде как симптом динамики образов. Tpyды CaнкmПетербургского гос. ин-та культуры. Вып. 1. 2013. С. 9-17.

7. Дианова В. М. Постмодернистская философия искусства : истоки и современность. Санкт-Петербург : Петрополис, 1999. 24 с.

8. Дольче Вита. Marie Claire. 2008. № 1. С. 165-167.

9. Ермилова Д. Ю. История домов моды. Москва : Академия, 2004. 288 с.

10. Зеллинг Ш. Мода. Век модельеров 1900-1999. Koln : Konemann, 1999. 658 с.

11. Кирьянов М. В. Социокультурные и эстетические аспекты формообразования в моде последней трети ХХ века : дисс. ... канд. культурологии : 24.00.01 / Ярослав. гос. пед. ун-т им. К. Д. Ушинского. Ярославль : ЯГПУ, 2011. $228 \mathrm{c}$.

12. Леонова К. І. Вплив естетики постмодернізму на художньо-стильові та пластично-образні особливості дизайну одягу початку ХХІ століття. Вісник ХДАДМ. 2016. № 1. С. 38-44. 
13. Маньковская Н. Б. Эстетика постмодернизма. Санкт-Петербург : Алетейя, 2000. 347 с.

14. Мерцалова М. Н. Костюм разных времен и народов. Т. 3-4. Москва : Академия моды, Санкт-Петербург : Чарт Пилот, 2001. 576 с.

15. Москвин А. Ю. Исторический крой в современном проектировании: от реминисценции до реконструкции. Фундаментальные и прикладнье исследования: проблемы и результаты : сборник материалов IX международной научно-практической конференции (16 декабря 2013 г., Новосибирск) / гл. ред. О. К. Арутюнян. Новосибирск : ЦРНС, 2013. C. $168-172$.

16. Москвин А. Ю. Проектирование мужской одежды на основе ретроспективного системного анализа конструктивных решений : дисс. ... канд. техн. наук. 17.00.06 / Санкт-Петербургский государственный университет технологии и дизайна. Санкт-Петербург : СПбГУТД, 2015. 239 с.

17. Москвин А. Ю. Ретроспективный анализ проявления исторических мотивов в модной форме костюма. Мир науки, культуры, образования. 2014. № 2. С. 271-274.

18. Москвин А. Ю. Элементы исторического кроя в современном художественном проектировании. Вестник молодых ученых Санкт-Петербургского государственного университета технологии и дизайна. Вып. 3 : Искусствоведение и дизайн. 2012. С. 62-65.

19. Наседкина Ю. В. Основные категории эстетики постмодернизма и их воплощение в современной моде. Мода в контексте культуры : сб. ст. четвёртой науч.-практ. конф. (21 апреля 2009 г., Санкт-Петербург) / под общ. ред. Г. Н. Габриэль. Санкт-Петербург : Изд-во СПбГУКИ, 2010. ВыП. 4. С. 81-87.

20. Шевнюк О. Л. Історія костюма : навчальний посібник. Київ : Знання, 2008. 375 с.

21. FALL 2004 COUTURE Christian Dior. URL: https://www.vogue.com/fashion-shows/fall-2004-couture/christiandior.

\section{REFERENCES}

1. Bilyakovych L. M. Temporal'nist' u strukturi modnykh trendiv: sutnist', dynamika, prohnozuvannya [Temporality in the Structure of Fashion Trends: Essence, Dynamics, Forecasts]. Bulletin of Lviv National Academy of Arts. 2018, № 36, pp. 207-222 [in Ukrainian].

2. Vankovych S. M. Kostyum perioda istorizma (problema vospriyatiya stilevykh prototipov) [The Costume of the Period of Historicism (The Problem of Perception of Style Prototypes)]: Diss. ... Candidate of Art History: 17.00.04 / The Russian Academy of Arts; Institute of Painting, Sculpture and Architecture named after Ilya Repin. St. Petersburg, 2001, 187 p. [in Russian].

3. Vankovych S. M. Proobrazy sovremennoy mody v aspekte obshchekhudozhestvennykh tendentsiy proshlykh epokh [Prototypes of Modern Fashion in the Aspect of General Artistic Tendencies of the Past Epochs]. Fashion and Design: Historical Experience and New Technologies: Special Edition of Bulletin of St. Petersburg State University of Industrial Technologies and Design. 2004, pp. 112-123 [in Russian].

4. Haludzina-Horobets V. I. Istoryzm u dyzayni odyahu druhoyi polovyny XX - pochatku XXI st.: geneza, dynamika, styl'ovi osoblyvosti [Historicism in the Design of the Clothes of the Second Half of the 20th Century and the Beginning of the 21st Century: Genesis, Dynamics, Style Features]: Diss. ... Ph. D. in Art History: 17.00.07 / Kyiv: Kyiv National University of Culture and Arts, 2019, 242 p. [in Ukrainian].

5. Guzavichute R. A. Issledovaniye stabil'nykh priznakov v proyektirovanii odezhdy XX veka [The Study of Stable Features in the Design of the Clothes of the 20th Century]: Diss. ... Candidate of Technical Sciences: 07.00.06. Moscow, 1997, 183 p. [in Russian].

6. Demshyna A. Yu. Retrospektivizm v sovremennoy mode kak simptom dinamiki obrazov [Retrospectivizm in the Modern Fashion as a Symptom of Dynamics of Images]. Papers of St. Petersburg State University of Culture and Arts. 2013, № 1, pp. 9-17 [in Russian].

7. Dianova V. M. Postmodernistskaya filosofiya iskusstva: istoki i sovremennost' [Postmodern Philosophy of Art: Origins and Modernity]. St. Petersburg: Petropolis, 1999, 240 p. [in Russian].

8. Dolce Vita. Marie Claire. 2008. № 1.pp. 165-167 [in Russian].

9. Yermilova D.Yu. Istoriya domov mody [The History of Fashion Houses]. Moscow, Russia: Academy, 2004,288 p. (Higher Education) [in Russian].

10. Zelling S. Moda. Vek model'yerov 1900-1999 [Fashion. Age of Fashion Designers 1900-1999]. Koln, Germany: Konemann, 1999, 658 p. [in Russian].

11. Kiryanov M.V. Sotsiokul'turnyye i esteticheskiye aspekty formoobrazovaniya v mode posledney treti XX veka [Socio-Cultural and Aesthetic Aspects of Shaping in the Fashion of the Last Third of the 20th Century]: Diss. ... Candidate of Cultural Science: 24.00.01 / Yaroslavl State Pedagogical University named after Konstantin Ushinsky. Yaroslavl: Yaroslavl State Pedagogical University, 2011, 228 p. [in Russian].

12. Leonova K.I. Vplyv estetyky postmodernizmu na khudozhn'o-styl'ovi ta plastychno-obrazni osoblyvosti dyzaynu odyahu pochatku XXI stolittya [The Influence of Aesthetics of Postmodernism on the Artistic-Stylistic and Plastic-Imaginative Features of the Design of Clothes at the Beginning of 21st Century]. Bulletin of Kharkiv State Academy of Design and Fine Arts. 2016, № 1. pp. 38-44 [in Ukrainian].

13. Mankovskaya N. B. Estetika postmodernizma [Aesthetics of Postmodernism]. St. Petersburg: Aletheya, 2000,347 p. [in Russian].

14. Mertsalova M. N. Kostyum raznykh vremen i narodov [Costume of Different Times and Nations]. Vol. 3-4. Moscow, Russia: Academy of Fashion, St. Petersburg, Russia: Chart Pilot, 2001, 576 p. [in Russian]. 
15. Moskvin A. Yu. Istoricheskiy kroy v sovremennom proyektirovanii: ot reministsentsii do rekonstruktsii [The Historical Cut in the Modern Design: From Reminiscence to Reconstruction]. Fundamental and Applied Researches: Problems and Results: a collection of materials of the IX International Scientific and Practical Conference (December 16, 2013, Novosibirsk) / chief ed., Professor O. K. Arutyunyan. Novosibirsk: Center for Development of Scientific Cooperation, 2013, pp. 168-172 [in Russian].

16. Moskvin A. Yu. Proyektirovaniye muzhskoy odezhdy na osnove retrospektivnogo sistemnogo analiza konstruktivnykh resheniy [Designing of Men`s Clothes on the Basis of Retrospective System Analysis of Design Solutions]: Diss. ... Candidate of Technical Sciences. 17.00.06 / St. Petersburg State University of Technologies and Design. St. Petersburg: St. Petersburg State University of Technologies and Design, 2015, 239 p. [in Russian].

17. Moskvin A. Yu. Retrospektivnyy analiz proyavleniya istoricheskikh motivov v modnoy forme kostyuma [Retrospective Analysis of Manifestation of Historical Motifs in the Fashionable Form of the Costume]. World of Science, Culture and Education. 2014, № 2, pp. 271-274 [in Russian].

18. Moskvin A. Yu. Elementy istoricheskogo kroya v sovremennom khudozhestvennom proyektirovanii [Elements of Historical Cut in the Contemporary Art Design]. Bulletin of Young Scientists of St. Petersburg State University of Technologies and Design. Vol. 3: Art Criticism and Design. 2012, pp. 62-65 [in Russian].

19. Nasedkina Yu. V. Osnovnyye kategorii estetiki postmodernizma i ikh voploshcheniye v sovremennoy mode [The Main Categories of Aesthetics of Postmodernism and Their Embodiment in the Modern Fashion]. Fashion in the Context of Culture: a coll. of artic. of the IV Scientific and Practical Conference (April 21, 2009, St. Petersburg) / chief ed. G.N. Gabriel. St. Petersburg: Publishing House of St. Petersburg State University of Culture and Arts, 2009, Vol. 4. pp. 81-87 [in Russian].

20. Shevnyuk O. L. Istoriya kostyuma: navch. posibnyk [The History of Costume: Work book]. Kyiv, Ukraine: Znannia, 2008, 375 p. [in Ukrainian].

21. FALL 2004 COUTURE. Christian Dior. URL: https://www.vogue.com/fashion-shows/fall-2004-couture/christiandior. 